\title{
Effects of Long-Term Nitrogen Fertilizer Application on Rhizosphere Microorganisms under Different Soil Types
}

\author{
Mingsong Li ${ }^{1,2}$, Tianye Wang ${ }^{1,2}$, Lin $\mathrm{Li}^{3}$, Qiang Gao ${ }^{1,2}$, Yunhang $\mathrm{Gao}^{4}$, \\ Shuxia Liu ${ }^{1,2 *}$, Hongbin Wang ${ }^{1,2 * *}$
}

${ }^{1}$ College of Resource and Environmental Science, Jilin Agricultural University, Changchun, China ${ }^{2}$ Key Laboratory of Soil Resource Sustainable Utilization for Jilin Province Commodity Grain Bases, Changchun, China ${ }^{3}$ School of Life Science, Jilin University, Changchun, China ${ }^{4}$ College of Animal Science and Technology, Jilin Agricultural University, Changchun, China

Received: 18 January 2018

Accepted: 27 March 2018

\begin{abstract}
The application of nitrogen fertilizers can improve the soil environment and influence the nutrition and quality of plants; there are also significant impacts of soil types on soil microbial communities. Research on the coupling effects between the rates of nitrogen fertilizer and the soil types on soil microbial metabolic activities under field conditions are currently lacking. In this study, we investigated the effect of five different $\mathrm{N}$ fertilization rates on three types of soils (meadow black, alluvial, and sandy soil) that were over 8-year-long planted maize. Illumina Miseq sequencing methods were used to characterize the soil microbial communities. Real-time PCR were adopted to calculate the relative abundance of $\mathrm{N}, \mathrm{C}$, and P-cycling functional microbial. Results indicated that different $\mathrm{N}$ rates can significantly change soil available nutrients and effectively reduce soil $\mathrm{pH}$. The structure of the soil bacterial communities and diversity did not change after the fertilization of $\mathrm{N}$ during the study period. However, it can be found that soil types can substantially influence the structure of bacterial communities in soil, meanwhile, there was a significant correlation between $\mathrm{pH}$ and the composition of bacterial communities. Although the composition of the soil microbial community did not influence the fertilization rate of $\mathrm{N}$, they can be indirectly affected by $\mathrm{pH}$. There was significant difference $(P<0.05)$ in the relative abundances of the nutrient cycling functional genes of the rhizosphere soil under different nitrogen levels, with nitrogen application and soil type the main influencing factors. The results showed that the excessive application of $\mathrm{N}$ fertilizer did not increase the yields of maize, thus it is important to investigate the reasonable fertilization rates of $\mathrm{N}$ fertilizer to protect the ecological balance of crop soils.
\end{abstract}

Keywords: rhizosphere soil, nitrogen levels, bacterial community, soil pH, real-time PCR

*e-mail: liushuxia2005824@163.com

**e-mail: WangHongbinatasionwang@163.com 


\section{Introduction}

Fertilization is an important agricultural practice. Nitrogen $(\mathrm{N})$ and phosphorus $(\mathrm{P})$ are important biological nutrients that have major impacts in controlling plant productivity and microbial functions [1]. Increasing $\mathrm{N}$ inputs to agricultural soils have had various adverse effects on soil quality, crop productivity, and ecosystem services [2-3]. The overuse of $\mathrm{N}$ fertilizers has resulted in concerns about crop production sustainability, including the costs of fertilizer inputs associated with the low $\mathrm{N}$ use efficiencies and degradation of the environment, such as greenhouse gas emissions [4]. The addition of fertilizers can have significant effects on soil microbial processes, key microbial community structures, and $\mathrm{N}$ availability - all of which are crucial for determining soil fertility, crop production, and $\mathrm{N}$ loss to the environment [5-6].

Soil microbial communities are extremely complex and diverse [7], and they play critical roles in regulating soil fertility, plant health, and nutrient cycling [8]. Microorganisms in agricultural soils are involved in nutrient supply, water use efficiency, degradation of harmful pollutants, control of pathogens, and the promotion of plant stress tolerance [9]. Numerous investigations have focused on the influence of $\mathrm{N}$ application to soil microbial communities [1, 3]. Previous studies have shown that long-term $\mathrm{N}$ application reduces microbial functional diversity [10]. For example, using phospholipid fatty acid analysis on soil microbial communities suggests that $\mathrm{N}$ fertilization significantly decreases microbial biomass in both clay and sandy soils [11]. Although some recent studies have suggested that a certain rate of $\mathrm{N}$ fertilization has no effect on soil microbial biomass and functional diversity [12], Lupwayi et al. (2012) found no difference in soil microbial biomass between treatments with urea applied at rates up to $90 \mathrm{~kg} \mathrm{~N} \mathrm{ha}^{-1}$ and no-till barley [12]. Similarly, Shen et al. (2016), using five different $\mathrm{N}$ fertilization rates, suggested that soil secondary salinization and acidification, brought on by high $\mathrm{N}$ fertilization rates, may be more important than previously thought in shaping the bacterial communities in intensively managed agricultural ecosystems [3]. Although the effects on soil nutrients, crop productivity, and microbial functions on increasing $\mathrm{N}$ fertilization rates are well documented, less is known about the effect of $\mathrm{N}$ application rates on different soil types [3, 12-13].

Information on the functional diversity of soil microbes is essential to elucidate the role of microbial communities in different environmental conditions [10]. The diversity of genetic information of soil bacteria is the basis of their functional and structural diversity and determines their different roles in soil [13]. As the main decomposer of plant organic residues, microorganisms can regulate the supply of nutrients that are needed by plants through the turnover of nutrients in the soil, affecting the growth and development of plants, structural composition, and resource allocation [11]. In addition, microorganisms can also convert nitrogen and phosphorus that cannot be absorbed directly by plants from the soil into a viable state [12].

Although a large number of biotic and abiotic factors are assumed to influence the structural and functional diversity of microbial communities, recent studies have largely focused on the influence of two factors: plant species and soil type [14-16]. Most studies have shown that soil is the main reservoir for rhizosphere microorganisms [14, 16]. Different soil types are assumed to harbor specific microbial communities, as recently shown in a continental-scale study of soil bacterial communities [14]. Ramirez et al. (2010) observed consistent effects of $\mathrm{N}$ fertilization on soil bacterial community composition in two contrasting ecosystems, but inconsistent changes in the richness and diversity of the bacterial communities [17]. At present, the effect of $\mathrm{N}$ fertilizer application rates on soil bacterial communities have no clear trends [18]. Marschner et al. (2001) concluded that the bacterial community composition in the rhizosphere is affected by a complex interaction between soil type, plant species, and root zone location [19]. Other studies showed soil type to be the dominant factor influencing the composition of the rhizosphere microbial community [20]. Da Silva et al. (2003) identified that soil type instead of maize cultivar type was the overriding determinative factor that influenced the community structures of Paenibacillus communities in the rhizosphere [20].

The application of synthetic nitrogen $(\mathrm{N})$ fertilizer to agricultural soils has increased 9 times from early 1961 to 2009 , but utilization efficiency of $\mathrm{N}$ decreased from $68 \%$ to $47 \%$, despite its having attempted to improve utilization efficiency of $\mathrm{N}$ worldwide [2]. Therefore, the reasonable fertilization rates of $\mathrm{N}$ still require urgent attention. Sustainable cultivation of maize, which is the main food crop in Asia, is very important in China. However, research on the coupling effects between the rates of nitrogen fertilizer and the soil types on soil microbial metabolic activities under field conditions are currently lacking. In order to provide information for this gap in current research, in this study a more than 8-year planted experiment field was conducted to study the influence of increasing $\mathrm{N}$ fertilization rate on the compositions of soil bacterial communities and the diversities under three soil types with the same climate conditions. A high throughput sequencing method was adopted. The results will suggest a suitable $\mathrm{N}$ fertilization rate for the growth of maize.

\section{Materials and Methods}

\section{Site Description and Experimental Setup}

The field site was located in Lishu County ( $43^{\circ} 32^{\prime}$ 'N, $\left.124^{\circ} 33^{\prime \prime} \mathrm{E}\right)$, Jilin Province, China. The research area has a temperate climate with around 144 frost-free 
Table 1. Nitrogen fertilization treatment, applied with urea ( $k g \mathrm{~N} \mathrm{ha}^{-1} \mathrm{y}^{-1}$ ), to each of the maize in each experimental field plot ${ }^{\mathrm{a}}$.

\begin{tabular}{|c|c|c|}
\hline Treatment & $\begin{array}{c}\text { Urea } \\
\left(\mathrm{kg} \mathrm{N} \mathrm{ha}^{-1} \mathrm{y}^{-1)}\right)\end{array}$ & Fertilization period \\
\hline N0 & 0 & \multirow{5}{*}{$\begin{array}{l}\text { For each treatment, } \\
\text { one-third of the } \mathrm{N} \text { fertilizer } \\
\text { was applied at planting and } \\
\text { the other two third was } \\
\text { side-dressed at the maize } \\
\text { (Zea mays L.) six-leaf stage }\end{array}$} \\
\hline N168 & 168 & \\
\hline N240 & 240 & \\
\hline N270 & 270 & \\
\hline N312 & 312 & \\
\hline
\end{tabular}

${ }^{a}$ Calcium superphosphate and potassium sulfate were applied as basal fertilizers at rates of $100 \mathrm{~kg} \mathrm{P}_{2} \mathrm{O}_{5} \mathrm{ha}^{-1}$ and $120 \mathrm{~kg}$ $\mathrm{K}_{2} \mathrm{O}^{-1} \mathrm{a}^{-1}$, respectively. Five fertilizer treatment rates abbreviated as M0, M168, M240, M270, M312 in meadow black soil; as A0, A168, A240, A270, A312 alluvial soil and as S0, S168, S240, S270, S312 in sandy soil.

days, an annual mean temperature of $5.6^{\circ} \mathrm{C}$, and annual precipitation of $594.8 \mathrm{~mm}$. The three soil types in the region are meadow black soil, alluvial soil, and sandy soil at Sankeshu $\left(43^{\circ} 20 \mathrm{~N}, 124^{\circ} 00 \mathrm{E}\right)$, Wangjiaqiao $\left(43^{\circ} 15^{\prime} \mathrm{N}, 124^{\circ} 29^{\prime \prime} \mathrm{E}\right)$, and Fujiajie ( $\left.43^{\circ} 21^{\prime \prime} \mathrm{N}, 124^{\circ} 05^{\prime} \mathrm{E}\right)$, respectively. The soil texture in the top $0.2 \mathrm{~m}$ consisted

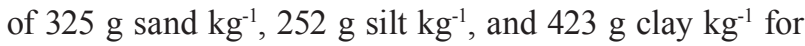
the meadow black soil, $477 \mathrm{~g}$ sand $\mathrm{kg}^{-1}, 296 \mathrm{~g}$ silt $\mathrm{kg}^{-1}$,

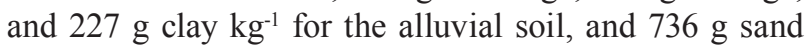
$\mathrm{kg}^{-1}, 96 \mathrm{~g}$ silt $\mathrm{kg}^{-1}$, and $108 \mathrm{~g}$ clay $\mathrm{kg}^{-1}$ for the sandy soil [11].

A continuous long-term fertilizer experiment was established in 2009. Table 1 shows the fertilization rates of N. Five fertilizer treatment rates (Table 1) were used, each treatment having three replicates. The experimental design was the same for all three sites, which resulted in a total of 45 plots. The total combined distance of the plots was less than four kilometers and they had the same phenological period. Each of the 45 plots measured $60 \mathrm{~m}^{2}(10 \mathrm{~m} \times 6 \mathrm{~m})$. All plots were cropped with maize in May and all maize residues were removed from the plots after harvest in October every year. Crop cultivation was undertaken without the use of plastic film.

\section{Soil Sampling and Analysis}

In September 2016, during the mature growth period of maize, soil rhizospheres were collected using the "shaking root" method; excess soil was gently shaken from the plant roots leaving rhizosphere soil in-situ on the plant roots, which was then collected for analysis [21]. From each research plot, nine randomized rhizosphere soil samples were collected and mixed to represent the experiment plot (a total of 15 soil samples). The soil samples were stored in a refrigerator and taken to the laboratory where they were sieved through a $2 \mathrm{~mm}$ mesh. About $10 \mathrm{~g}$ of each sample was frozen and stored at $-80^{\circ} \mathrm{C}$ until DNA extraction was undertaken; the remainder of the sample was stored at $4^{\circ} \mathrm{C}$ for chemical analyses.

Soil moisture was determined after drying at $105^{\circ} \mathrm{C} 8 \mathrm{~h}$; soil $\mathrm{pH}$ was measured on a $2: 5(\mathrm{w} / \mathrm{v})$ ratio in distilled water using a $\mathrm{pH}$ meter; total organic $\mathrm{C}$ was determined by dichromate oxidation; and total $\mathrm{N}$ by Kjeldahl digestion. Soil TP was determined colorimetrically using the molybdate method. Soil available phosphorus (AP) was determined colorimetrically based on the Olsen method [22], and available potassium (AK) was determined by the ammonium acetate extraction procedure. Microbial biomass carbon (MBC) and microbial biomass nitrogen $(\mathrm{MBN})$ were determined using the chloroform fumigation extraction method [23]. Soil nitrate nitrogen $\left(\mathrm{NO}_{3}{ }^{-} \mathrm{N}\right)$ and ammonium nitrogen $\left(\mathrm{NH}_{4}{ }^{+} \mathrm{N}\right)$ were extracted from $15 \mathrm{~g}$ fresh soil with $2 \mathrm{M} \mathrm{KCl}$ (soil: extract/1:5) and analyzed using a flow-injection autoanalyzer (Skalar San++, Netherlands).

\section{SrDNA and Real-Time PCR Analysis}

Soil DNA was extracted from $0.4 \mathrm{~g}$ of frozen soil using a MoBioPowersoil DNA Isolation Kit, according to the manufacturer's protocol. Extracted DNA was then purified using the GV-High-Efficiency Agarose Gel DNA Purification Kit, DNA concentrations were determined using the Qubit quantification platform with a Quant-iT ESDNA BR assay kit (Invitrogen). DNA was diluted to $10 \mathrm{ng} \mathrm{ml}^{-1}$ and stored at $-80^{\circ} \mathrm{C}$ prior to molecular analysis.

Aliquots (10 ng) of purified DNA from each sample were used as templates for amplification. The V3-V4 hypervariable regions of the bacterial 16SrRNA genes were amplified using the primer set U341F (ACT CCTACGGGAGGCAGC AG) and U806R (GGA CTA CHVGGGTWT CTA AT). The 16SrDNA high-throughput sequencing was performed by the Realbio Genomics Institute (Shanghai, China) using the Illumina MiSeq platform. The raw data were then subjected to a quality control procedure using UPARSE [24]. The qualified reads were clustered to generate operational taxonomic units (OTUs) at the 97\% similarity level using USEARCH [25]. A representative sequence for each OTU was assigned to a taxonomic level in the RDP database by the RDP classifier [26].

The abundances of genes (nifH, archaeal amoA, bacterial amo $A, n o s Z, c b b l$ and $g d h 3$ ) encoding the key enzymes for biological $\mathrm{N}$ cycling were quantified by real-time PCR (IBA7500) for all soil samples. These methods were modified from their original descriptions (references following primers) (Table 1). Gel-purified PCR products from a common DNA mixture (equal amounts of DNA from all samples) were used to prepare sample-derived quantification standards [27]. The copy number of genes in each standard was calculated by DNA concentration $\left(\mathrm{ng} \cdot \mu \mathrm{L}^{-1}\right.$, measured by Qubit) divided by average molecular weight (PCR 
0
0
0
0

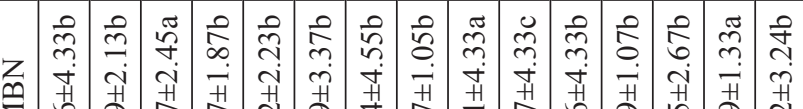

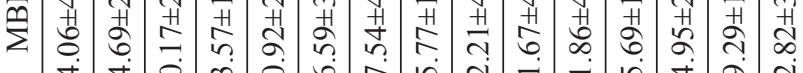

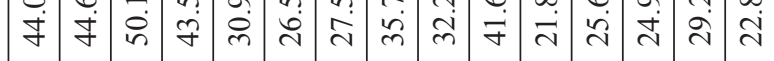

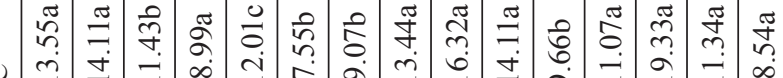

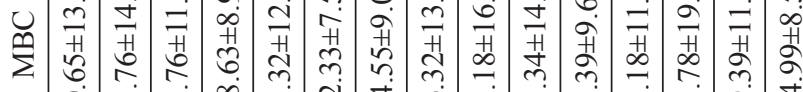

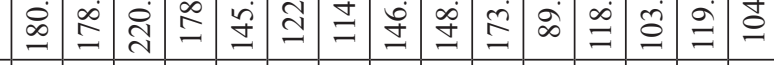

:

$\sum^{i}$

$\ddot{0}$

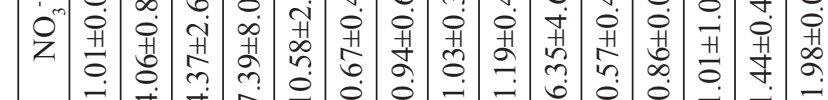

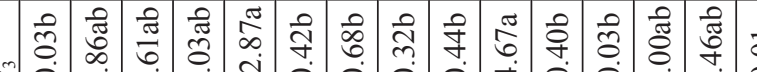

ㄴ.

胥

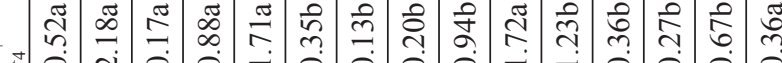

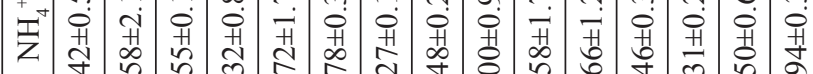

논

当

ב

$\Xi \stackrel{8}{(0}$

龸

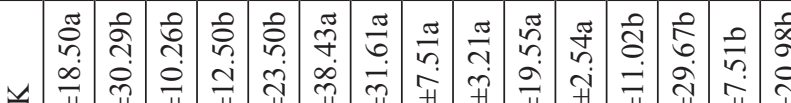

茾 $\begin{gathered}\text { H } \\ m\end{gathered}$

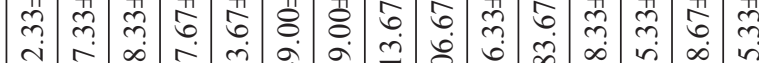

छै

范

3

曾

3

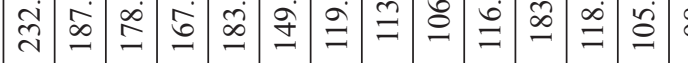

盛

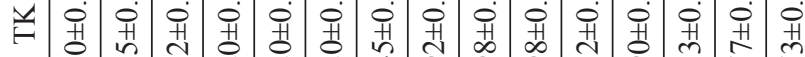

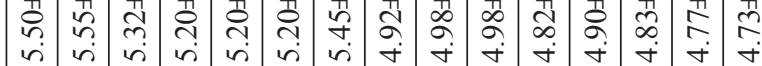

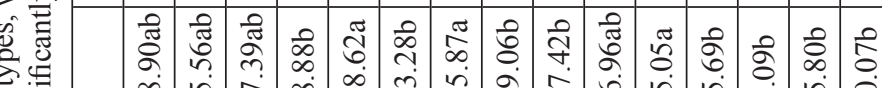

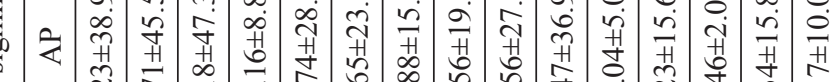

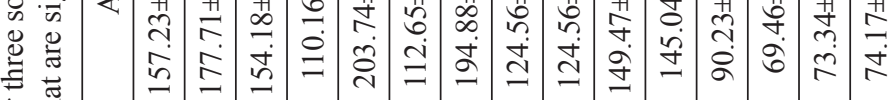
离

纪贲

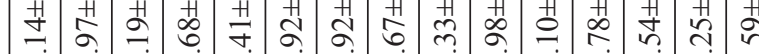

莺

. $\infty$ i 0 in

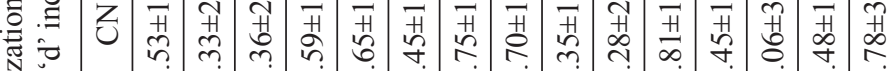

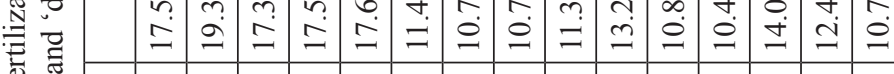

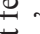

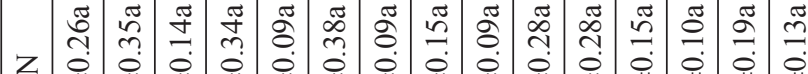

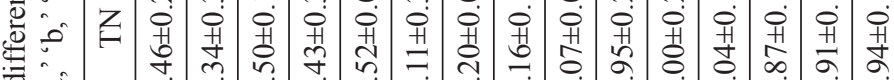
苛

t)

$\stackrel{\mathscr{\theta}}{=} \overline{\overline{0}}$

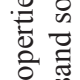

己.

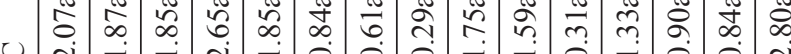

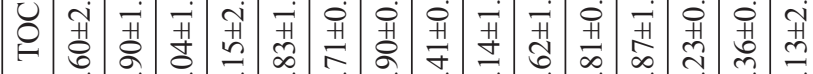

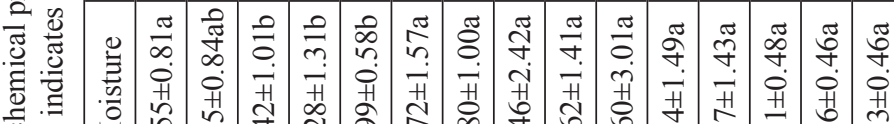

o

न

远

की

골

吾

i

剀

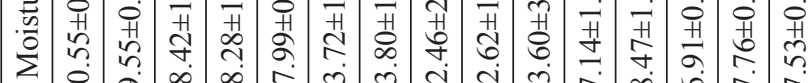

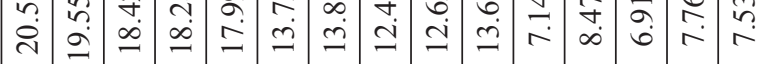

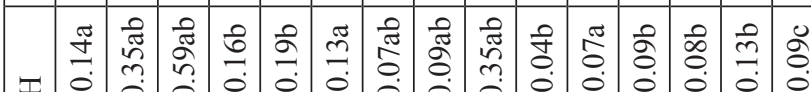

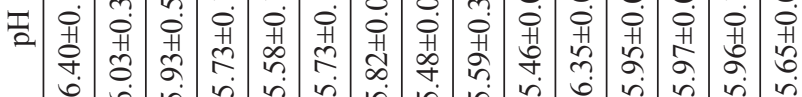

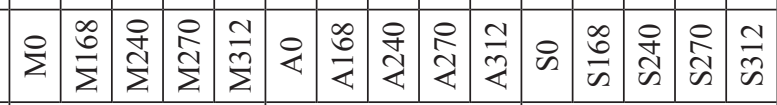

.

$$
\varangle
$$




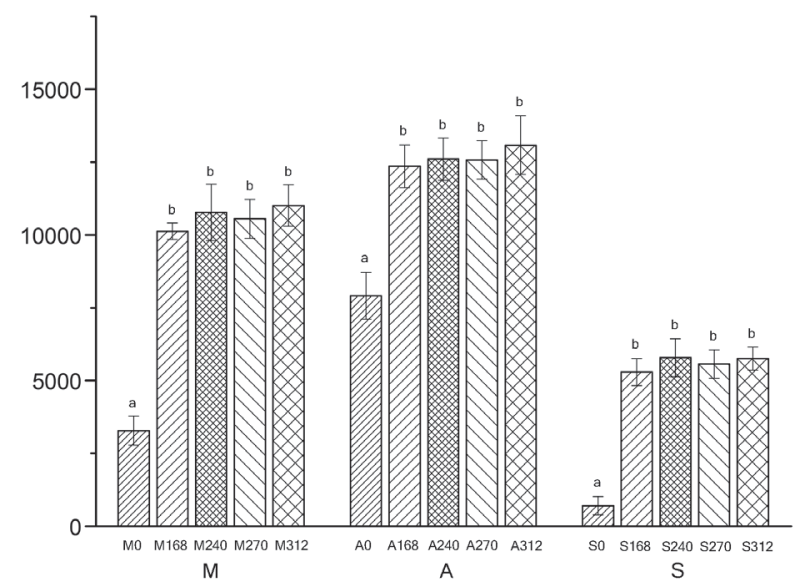

Fig. 1. Maize yields under the application of $\mathrm{N}$ fertilizers at five rates with three soil types. "M" indicates Meadow black soil, "A" indicates alluvial soil, and " $\mathrm{S}$ " indicates sand soil. Letters ' $\mathrm{a}$,' 'b,' 'c,' and 'd' indicate contrasts that are significantly different $(\mathrm{P}<0.05)$ between different treatments.

product length and GC content was obtained from barcoded-pyrosequencing results) of the amplified gene fragment [28].

\section{Statistical Analysis}

The results were expressed as the means and standard deviations. Figures were plotted with Origin 8.1 software. All analyses were performed in the corrplot package in R. Analysis of one-way analysis of variance (ANOVA) was used to determine the significance of the differences in relative abundances of taxa, soil parameters, and maize yields. The correlations analyses were using Pearson correlations. Statistical significance was set at $P<0.05$. Alpha diversity was measured using Chaol, observed species, Shannon,
Simpson, goods coverage, and PD whole tree [29]. Beta diversity was ordinated by principal coordinates analysis (PCoA) using the vegan package of Rv.3.1.1 project [30]. Weighted Unifrac scores between all pairs of samples were used as the basis for principal coordinates analysis (PCoA), for hierarchical clustering analysis, and for heatmap. Analysis of similarities (ANOSIM, 999 permutations) was used to evaluate the null hypothesis of no difference between groups. In addition, redundancy analysis (RDA) was performed, which is an extension of principal components analysis in which the main components are constrained to be linear combinations of the environmental variables. To determine the environmental factors that significantly correlated with community composition (abundance of OTUs), we used the function envfit (999 permutations) in the vegan package of $\mathrm{R}$ v.3.1.1 project.

\section{Results}

\section{Effects of Fertilization Rates of Nitrogen on Physical and Chemical Properties of Rhizosphere Soil and Maize Yield}

Results of soil total nutrients (TN, TOC, TP and TK) showed no significant differences $(P>0.05)$ among the different $\mathrm{N}$ fertilization rates; however, the total nutrient content was obviously different among the three soil types (Table 2). Results of soil available nutrients showed that there was a significant influence in different fertilization rates of $\mathrm{N}(P<0.05)$. The results indicated that available potassium (AK) in S0 was higher than that in the other treatments that input $\mathrm{N}$ input treatments; the application of $\mathrm{N}$ fertilizer significantly decreased $(P<0.05)$ AK content in the rhizosphere soil. $\mathrm{NO}_{3}$ - values in soil were highest in M312, A312, and S312 in the meadow black, alluvial, and sandy soils, respectively;
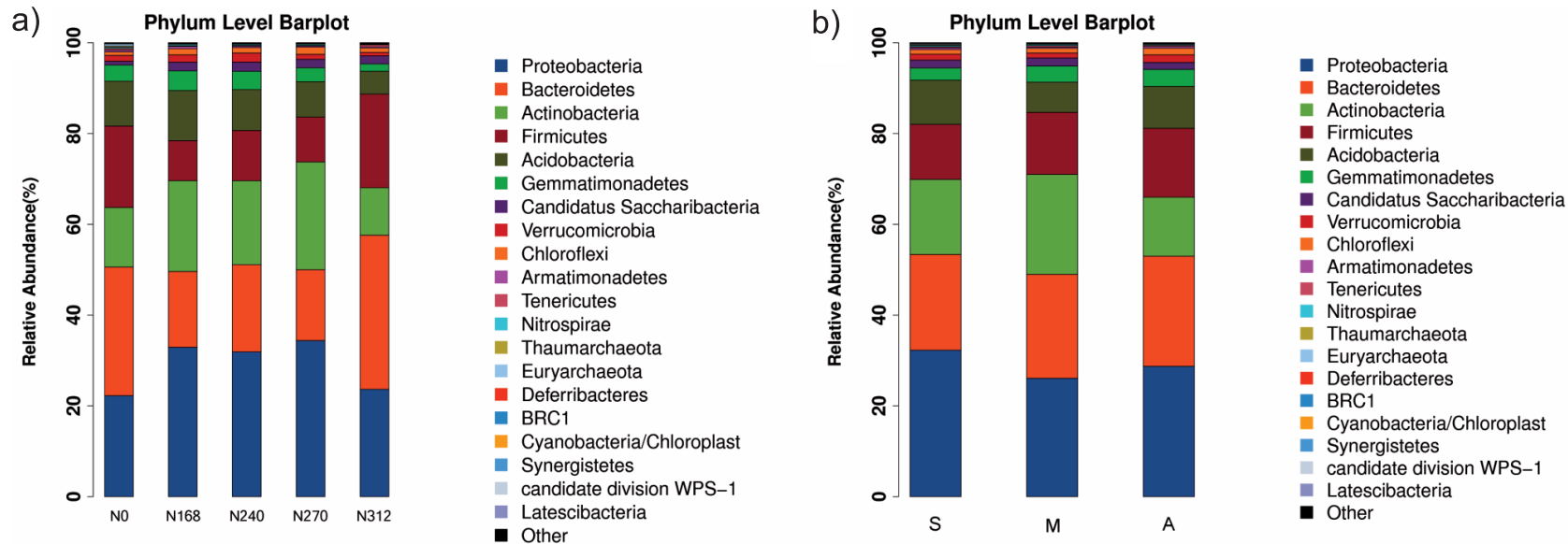

Fig. 2. Relative abundances of the dominant bacterial phyla in soils separated according to $\mathrm{N}$ fertilizers at five rate and soil types. Relative abundances are based on the proportional frequencies of those DNA sequences that could be classified at the phylum level. "A" was separated according to "N" fertilizer rates, "B" was separated according to three soil types, "S" indicates sand soil, "M" indicates meadow black soil, and "A" indicates alluvial soil. 


\section{Weighted Unifrac Distance}

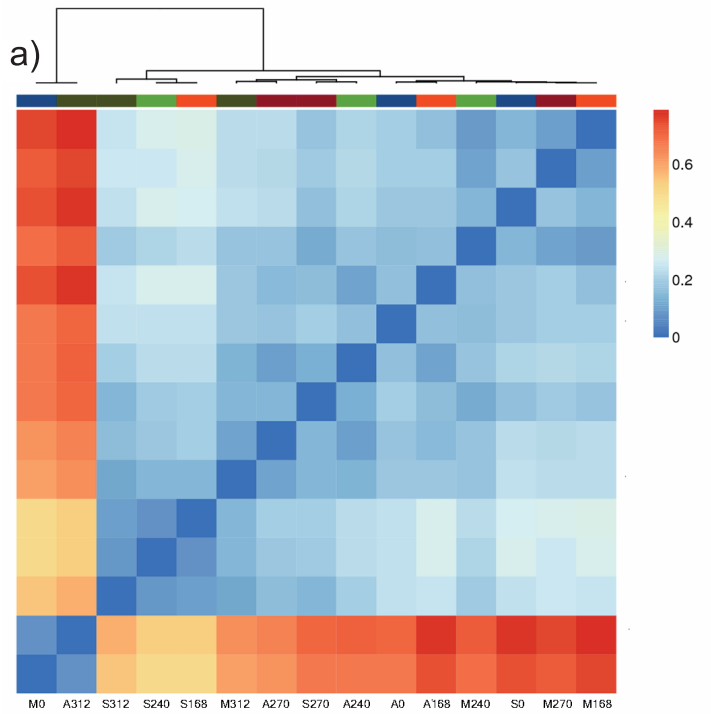

b)
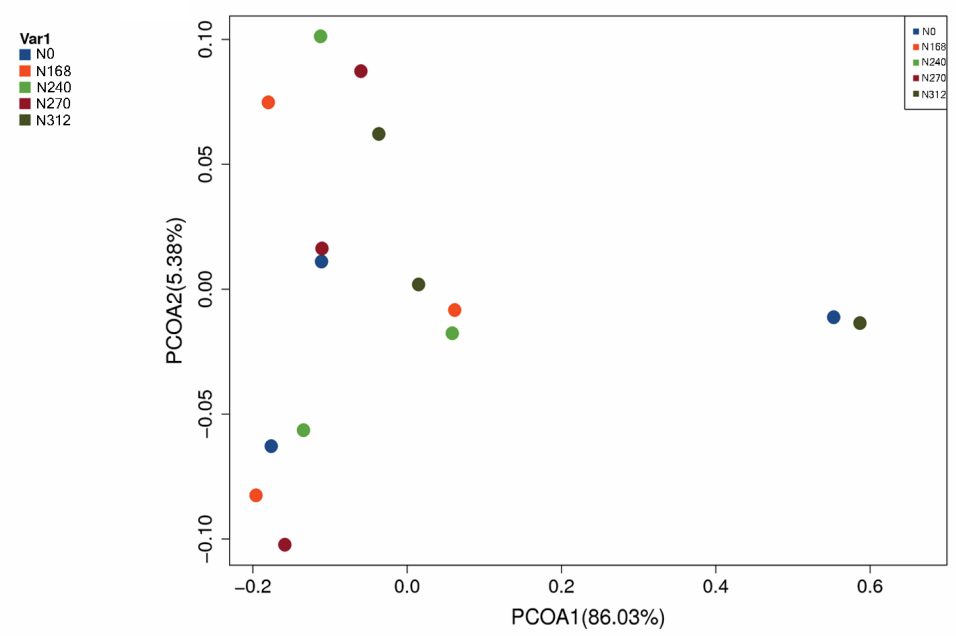

Fig. 3. a) Pairwise comparison of $\beta$-diversity with all samples and annotation and according to the different $\mathrm{N}$ application group. Clustering and heatmap were computed using the weighted Unifrac scores. b) The principal coordinates analysis (PCoA) plot of community composition based on pyrosequencing of microbial communities of five $\mathrm{N}$ application levels.

$\mathrm{NH}_{4}^{+}$results were also the greatest in $\mathrm{A} 312$ and $\mathrm{S} 312$, but there was no significant difference $(P>0.05)$ between the different $\mathrm{N}$ input treatments in the meadow black soil. Soil $\mathrm{pH}$ values were lowest in the M312, A312, and $\mathrm{S} 312$ treatment plots and highest in the M0, A0, and $\mathrm{S} 0$ treatment plots. The $\mathrm{pH}$ results in the sandy soil were noticeably higher in the S0 treatment than in the other $\mathrm{N}$ input treatments. The value of $\mathrm{MBC}$ and MBN was significantly different $(P<0.05)$ in the three soil types (Table 2). Results for treatment plots with no additional $\mathrm{N}$ fertilizer were lower than those with $\mathrm{N}$ fertilization treatments for the three soil types $(P<0.05$,

Table 3. Real-time PCR quantification of the N-transforming function genes (archaeal $a m o A$, bacterial $a m o A, c b b l, n i f H, n o s Z$ and $g d h 3$ ) between different fertilization treatments under three soil types; the copy number of genes in each gram of dry soil was estimated based on the results of real-time PCR (copies per ng DNA); the standard curve of all these genes was $>0.99$, and 'a,' 'b,' 'c,' and 'd' indicate contrasts that are significantly different $(P<0.05$ ) among different treatments; each sample was measured in triplicate.

\begin{tabular}{|c|c|c|c|c|c|c|}
\hline & AOA & AOB & $c b b l$ & $n i f H$ & $n o s Z$ & $g d h 3$ \\
\hline M0 & $6.931 \pm 0.006 \mathrm{ab}$ & $6.424 \pm 0.056 \mathrm{~d}$ & $7.038 \pm 0.040 \mathrm{c}$ & $7.280 \pm 0.037 \mathrm{ab}$ & $6.770 \pm 0.037 \mathrm{cde}$ & $7.243 \pm 0.002 \mathrm{bc}$ \\
\hline M168 & $6.912 \pm 0.026 \mathrm{abc}$ & $7.029 \pm 0.003 \mathrm{ab}$ & $7.238 \pm 0.021 \mathrm{ab}$ & $6.793 \pm 0.075 \mathrm{def}$ & $6.908 \pm 0.032 \mathrm{ab}$ & $6.836 \pm 0.126 \mathrm{~g}$ \\
\hline M240 & $6.878 \pm 0.020 \mathrm{abc}$ & $7.037 \pm 0.005 \mathrm{a}$ & $7.279 \pm 0.013 \mathrm{a}$ & $7.016 \pm 0.050 \mathrm{bcd}$ & $6.840 \pm 0.038 \mathrm{bc}$ & $7.219 \pm 0.001 \mathrm{cde}$ \\
\hline M270 & $6.912 \pm 0.033 \mathrm{abc}$ & $7.038 \pm 0.002 \mathrm{a}$ & $7.278 \pm 0.044 \mathrm{a}$ & $7.000 \pm 0.092 \mathrm{bcd}$ & $6.820 \pm 0.004 \mathrm{c}$ & $7.116 \pm 0.029 \mathrm{ef}$ \\
\hline M312 & $6.903 \pm 0.029 \mathrm{abc}$ & $7.013 \pm 0.003 \mathrm{ab}$ & $7.279 \pm 0.085 \mathrm{a}$ & $7.047 \pm 0.142 \mathrm{bcd}$ & $6.723 \pm 0.025 \mathrm{de}$ & $7.264 \pm 0.013 \mathrm{abc}$ \\
\hline A0 & $6.797 \pm 0.081 \mathrm{bcd}$ & $6.343 \pm 0.276 \mathrm{~d}$ & $7.065 \pm 0.113 \mathrm{c}$ & $7.215 \pm 0.249 \mathrm{abc}$ & $6.713 \pm 0.047 \mathrm{e}$ & $6.866 \pm 0.132 \mathrm{~g}$ \\
\hline A168 & $5.979 \pm 0.101 \mathrm{f}$ & $6.912 \pm 0.010 \mathrm{bc}$ & $6.729 \pm 0.043 \mathrm{de}$ & $7.049 \pm 0.138 \mathrm{bcd}$ & $6.708 \pm 0.005 \mathrm{e}$ & $6.400 \pm 0.157 \mathrm{~h}$ \\
\hline A240 & $5.975 \pm 0.160 \mathrm{f}$ & $6.909 \pm 0.002 \mathrm{bc}$ & $7.046 \pm 0.039 \mathrm{c}$ & $7.074 \pm 0.081 \mathrm{bcd}$ & $6.833 \pm 0.029 \mathrm{c}$ & $7.364 \pm 0.002 \mathrm{a}$ \\
\hline A270 & $5.809 \pm 0.356 \mathrm{f}$ & $6.924 \pm 0.008 \mathrm{ab}$ & $6.804 \pm 0.148 \mathrm{~d}$ & $7.038 \pm 0.074 \mathrm{bcd}$ & $6.716 \pm 0.018 \mathrm{de}$ & $7.135 \pm 0.014 \mathrm{def}$ \\
\hline A312 & $6.733 \pm 0.071 \mathrm{cde}$ & $6.925 \pm 0.002 \mathrm{ab}$ & $7.266 \pm 0.027 \mathrm{a}$ & $6.642 \pm 0.418 \mathrm{f}$ & $6.973 \pm 0.038 \mathrm{a}$ & $7.046 \pm 0.044 \mathrm{f}$ \\
\hline S0 & $7.018 \pm 0.014 \mathrm{a}$ & $6.797 \pm 0.015 \mathrm{c}$ & $7.124 \pm 0.025 \mathrm{bc}$ & $7.485 \pm 0.005 \mathrm{a}$ & $6.788 \pm 0.049 \mathrm{~cd}$ & $7.218 \pm 0.016 \mathrm{ef}$ \\
\hline S168 & $6.858 \pm 0.018 \mathrm{abc}$ & $6.923 \pm 0.011 \mathrm{bc}$ & $6.628 \pm 0.030 \mathrm{e}$ & $6.618 \pm 0.319 \mathrm{f}$ & $6.145 \pm 0.101 \mathrm{~g}$ & $7.343 \pm 0.001 \mathrm{ab}$ \\
\hline S240 & $6.870 \pm 0.041 \mathrm{abc}$ & $6.986 \pm 0.006 \mathrm{ab}$ & $7.012 \pm 0.160 \mathrm{c}$ & $6.943 \pm 0.054 \mathrm{~cd}$ & $6.404 \pm 0.023 \mathrm{f}$ & $7.237 \pm 0.011 \mathrm{bcd}$ \\
\hline S270 & $6.555 \pm 0.154 \mathrm{e}$ & $6.923 \pm 0.015 \mathrm{ab}$ & $6.773 \pm 0.070 \mathrm{~d}$ & $6.930 \pm 0.127 \mathrm{cde}$ & $6.209 \pm 0.056 \mathrm{~g}$ & $7.284 \pm 0.019 \mathrm{abc}$ \\
\hline S312 & $6.614 \pm 0.073 \mathrm{de}$ & $6.958 \pm 0.004 \mathrm{ab}$ & $7.102 \pm 0.128 \mathrm{c}$ & $6.651 \pm 0.133 \mathrm{ef}$ & $6.067 \pm 0.068 \mathrm{~h}$ & $7.246 \pm 0.002 \mathrm{bc}$ \\
\hline
\end{tabular}


Fig. 1). No significant differences among the treatments for the five different $\mathrm{N}$ applied rates $(P>0.05$, Fig. 1) were also found. Maize yield was highest in the alluvial soil and lowest in the sandy soils.

\section{Effects of Different Fertilization Rates of Nitrogen on the Microbial Communities of Rhizosphere Soil}

In order to study the effect of $\mathrm{N}$ fertilizer application on rhizosphere soil, we treated the same $\mathrm{N}$ fertilizer applied in different soils as the same treatment. A total of 2.5 million high-quality 16SrDNA gene sequence reads were obtained from the 15 samples. 84,161 distinct OTUs (observations) across the samples were assigned to these OTUs, this observation referring to the number of distinct OTUs, whereas the count refers to the abundance of bacteria belonging to these OTUs in the samples. Good's coverage for the bacterial data across the 15 samples was $97.17 \%$ on average. Chaol, observed species, Shannon, Simpson, Good's coverage, and PD whole tree metrics were used to calculate a lpha diversity (species diversity within the community; Table 2). Although $\mathrm{N} 312$ fertilization treatment had

\section{Alpha diff boxplot}
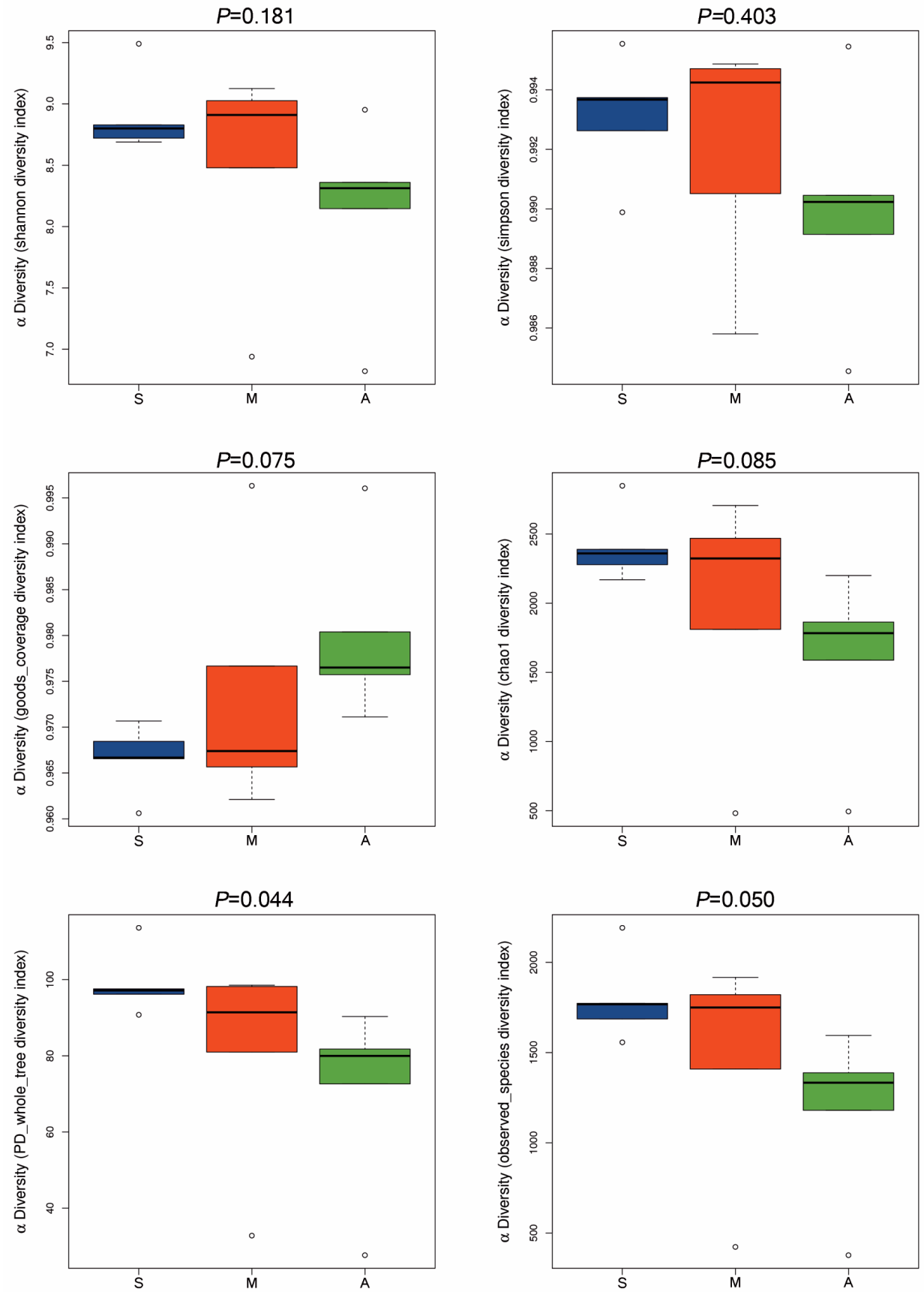

Fig. 4. Value of bacterial alpha diversity in the rhizosphere under different soil types. 
a)

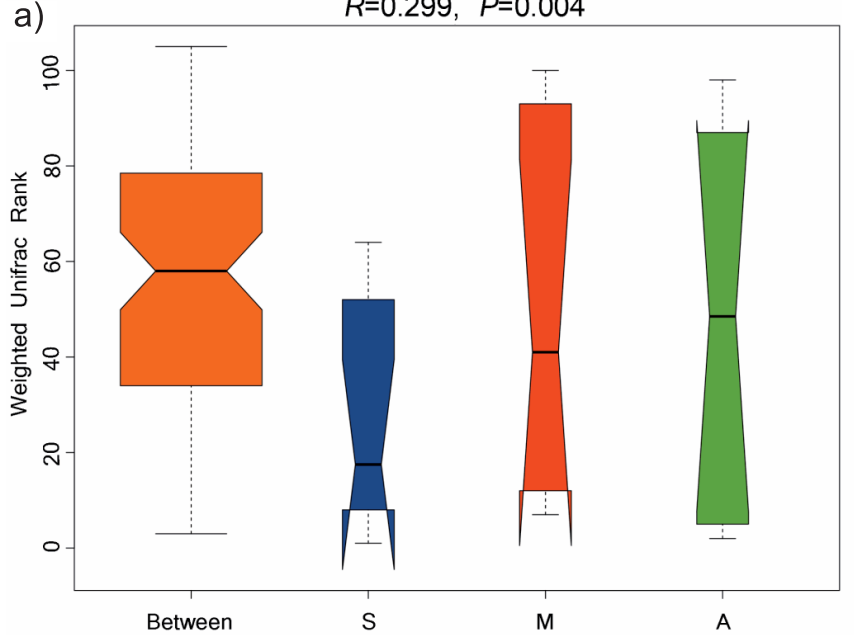

b)

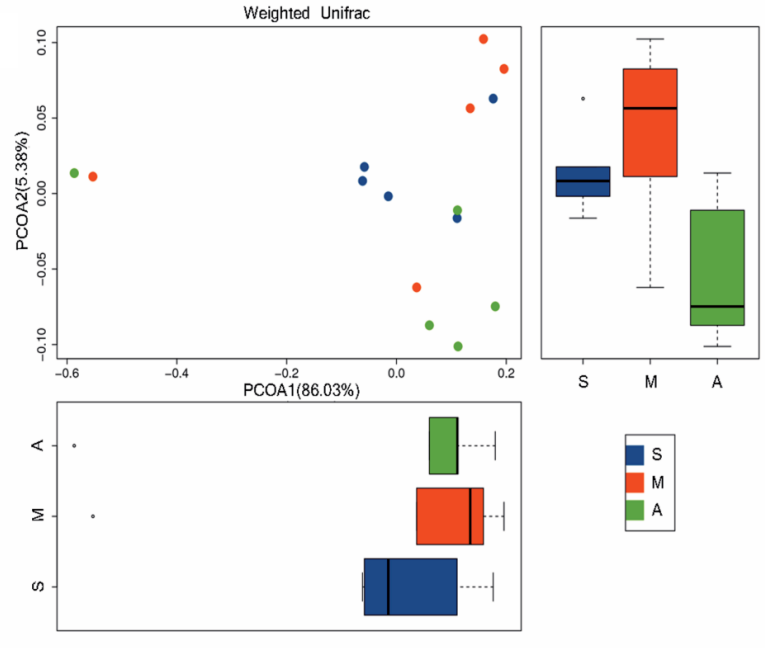

Fig. 5. a) Analysis of similarities (ANOSIM, 999 permutations) was used to evaluate the null hypothesis of groups based on weighted Unifrac distances. b) Principal coordinate analysis ( $\mathrm{PCoA}$ ) of three soil types. The resulting plots of 15 samples. "M" indicates Meadow black soil, "A" indicates alluvial soil, and "S" indicates sand soil.

the lowest alpha diversity and N168 had the highest alpha diversity, there were no significant differences $(P>0.05)$ among the $\mathrm{N}$ fertilizer treatments for alpha diversity (Table 2).

Taxonomic summary of the relative abundance of bacteria (Fig. 2a) showed that rhizosphere soil microbial communities differed between the five $\mathrm{N}$ fertilization treatments. In terms of the response of the bacterial community to the different $\mathrm{N}$ treatments, Proteobacteria (29\%) was the most dominant phylum, Bacteroidetes (23\%) the second most abundant phylum, and Actinobacteria (17\%) the third most dominant (Fig. 2a). Weighted-unifracheatmap (Fig. 3a) and principal coordinate analysis (PCoA) (Fig. 3b) showed that the same $\mathrm{N}$ fertilization treatment could not be clustered together and that soil microbial communities in different $\mathrm{N}$ fertilization treatments did not differ significantly. Only five genes were found to have a significant difference among the five $\mathrm{N}$ fertilization treatments (Table 3).

\section{Effects of Different Soil Types on the Microbial Communities of Rhizosphere Soil}

A non-parametric test was used to analyze the diversity of rhizosphere soil microbial communities between the three soil types. Results from this analysis showed that observed species and PD whole tree metrics were significantly different between the soil types (Fig. 4), but other alpha diversity indices were not, and alluvial soil (A) had the lowest alpha diversity (Fig. 4).

Taxonomic summary of the relative abundance of bacteria (Fig. 2b) showed that rhizosphere soil microbial communities differed between the three soil types regardless of $\mathrm{N}$ fertilizer application rates. There were significant differences in the relative abundances of BRC1, but relative abundances were lower (Fig. 2b).
PCoA showed a significant difference $(P=0.004)$ in the rhizosphere soil microbial communities between the three soil types (Fig. 5). Forty-three genes were significantly different between the three soil types (Table 4), among these, the relative abundance of Rhizobium in clay soil was higher $(P<0.05)$ than in alluvial soil (A) and meadow black soil (M). Because the soil parameters were different in the three soil types, we used RDA ordination biplot to detect which parameter was the main factor influencing rhizosphere soil microbial communities $(P=0.035$; Fig. 6). Results revealed that only $\mathrm{pH}$ had a significant influence on soil microbial community, the value of TN was not the main factor. Correlation analysis showed

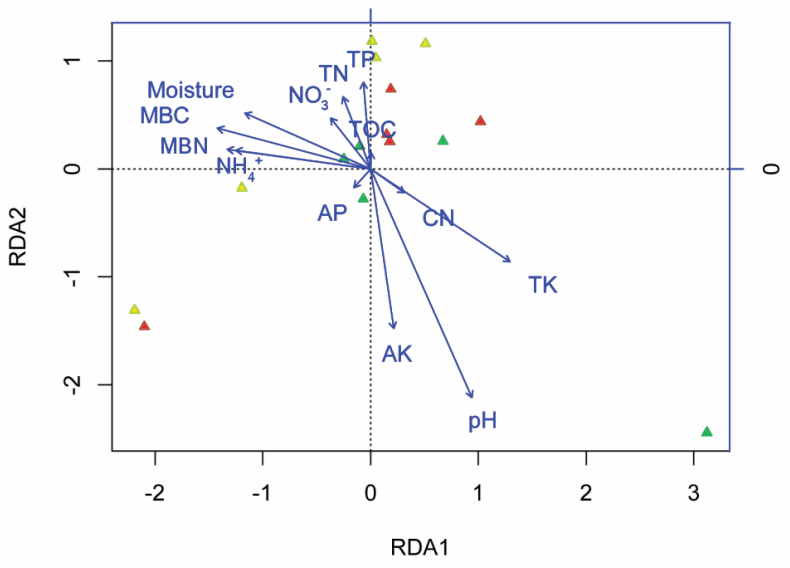

Fig. 6. Redundancy analysis (RDA) triplots of $16 \mathrm{~S}$ rDNA fingerprint patterns showing the contribution of 13 environmental parameters to variability. Arrows indicate environmental factors and their relative effects on microbial community structure. The red triangles indicate Meadow black soil, yellow triangles indicate alluvial soil, green triangles indicate sand soil. 

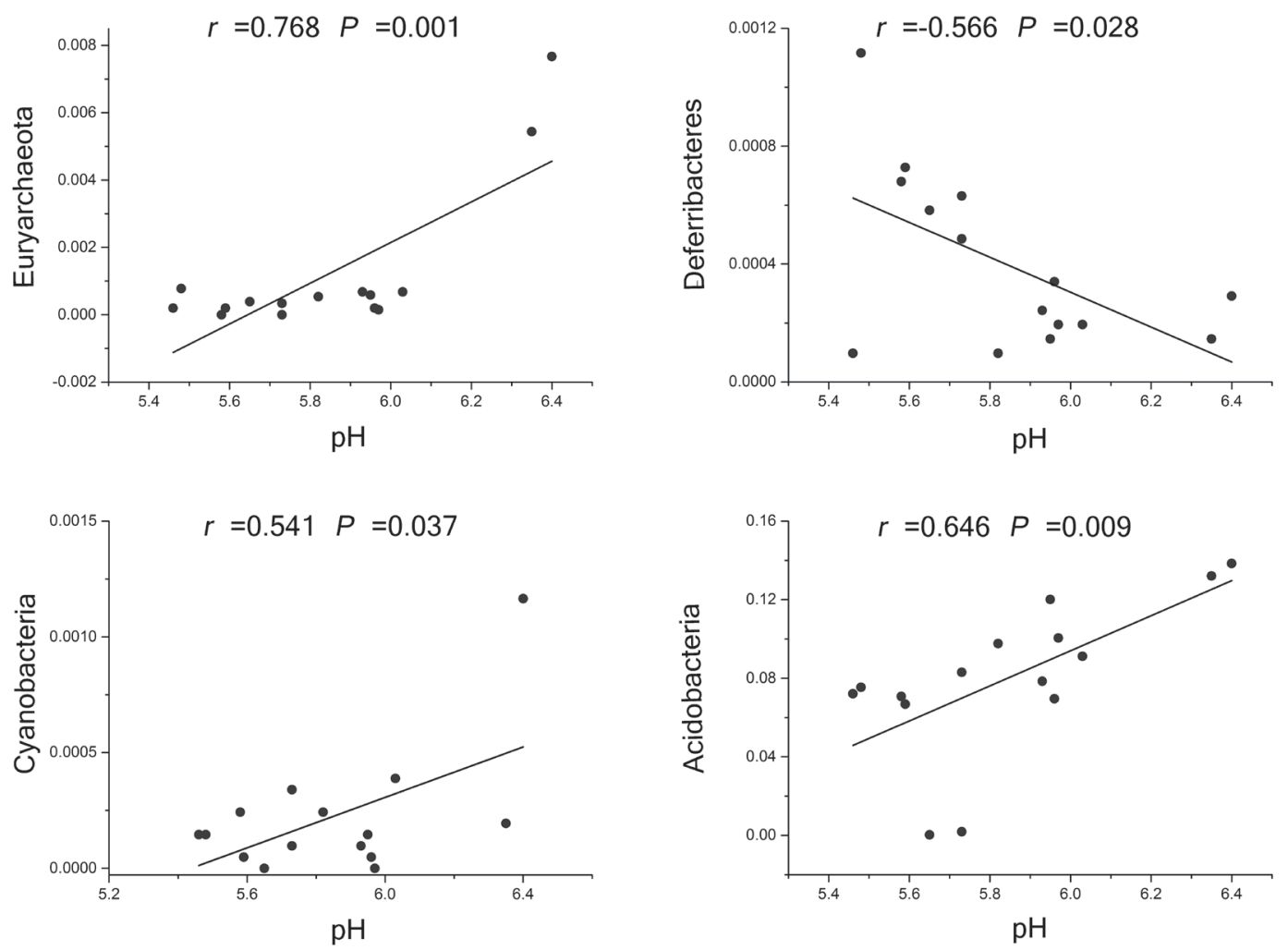

Fig. 7. Pearson correlations between four four main phyla relative abundance and $\mathrm{pH}$-value.

that four main phyla were significantly correlated to $\mathrm{pH}$ (Fig. 7).

\section{Relative Abundance of Functional Microbial}

For nitrogen cycling functional microorganisms in the different soil types, the abundances of AOA, AOB, and $c b b l$ in the meadow black soil (M168, M240, M270, and M312) were higher than that in the sand soil (S168, S240, S270, and S312) and the alluvial soil (A168, A240, A270 and A312) $(P<0.05$, Table 3). However, the abundances of AOA, AOB, cbbl, and nifH in sand soil was highest without nitrogen fertilizer treatment. Furthermore, nos $Z$ function gene copy number showed that all the M0, M168, and M240 of the meadow black soil were higher than that of the sand soil and the alluvial soil under the same level of nitrogen fertilizer. Nevertheless, under N270 and N312 levels of nitrogen fertilizer, nos $Z$ function gene copy number in alluvial soil was highest $(P<0.05$, Table 3$)$. Between the different levels of nitrogen fertilizer, it can be found that the abundances of AOB in the sand soil and the alluvial soil were on the rise with the increasing nitrogen fertilizer rate, as well as the abundance of $c b b l$ in the meadow black soil. Conversely, it showed that the abundance of nos $Z$ in the meadow black soil and the abundance of nifH in the alluvial soil was decreasing with the increasing nitrogen fertilizer rate. Whereas there was not an obvious change in $g d h 3$ gene copy number under the different nitrogen fertilizer rates in all the sand soil, the alluvial soil, and the meadow black soil $(P>0.05$, Table 3).

The results of the two-way ANOVA showed that the abundance of AOA had significant positive correlations with $\mathrm{CN}(\mathrm{r}=0.529, P<0.05)$ and $\mathrm{AK}(\mathrm{r}=0.594, P<0.05)$ (Table 4). At the same time, there were significant positive correlations in the abundance of $c b b l$ with the soil-water content $(\mathrm{r}=0.516, P<0.05)$, TOC $(\mathrm{r}=0.606$, $P<0.05), \mathrm{CN}(\mathrm{r}=0.646, P<0.01), \mathrm{AK}(\mathrm{r}=0.550, P<0.05)$, $\mathrm{NH}_{4}^{+}(\mathrm{r}=0.736, P<0.01), \mathrm{NO}_{3}^{-}(\mathrm{r}=0.676, P<0.01)$, MBC ( $\mathrm{r}=0.530, P<0.05)$, and MBN ( $\mathrm{r}=0.532, P<0.05)$ (Table 4), as well as the abundance of nos $Z$ with the soil water content $(\mathrm{r}=0.683, P<0.01)$, TP $(\mathrm{r}=0.583$, $P<0.05), \mathrm{NH}_{4}^{+}(\mathrm{r}=0.515, P<0.05), \mathrm{MBC}(\mathrm{r}=0.629$, $P<0.05)$, and $\mathrm{MBN}(\mathrm{r}=0.573, P<0.05)$ (Table 4). Although TK was a significantly positively correlative with the abundance of $\operatorname{nos} Z(\mathrm{r}=0.571, P<0.05)$, there was a significantly negative correlation between TK and the abundance of $g d h 3(\mathrm{r}=-0.559, P<0.05)$ (Table 4).

\section{Discussion}

\section{Effects on Soil Properties and Maize Yields}

For each treatment, the properties of rhizosphere soil properties and the maize yields of five fertilization rates of $\mathrm{N}$ in the three soil types were examined, and each treatment was thoroughly mixed from 5 random subsamples. The results indicate that the total nutrients 
Table 4. Pearson correlations between C, N, P-cycling functions gene abundance and soil properties, stronger colour (red is positive, blue is negative) in the heatmap indicate a stronger effect

\begin{tabular}{|c|c|c|c|c|c|c|}
\hline & AOA & AOB & $c b b l$ & nifH & nosZ & gdh3 \\
\hline $\mathrm{pH}$ & 0.498 & -0.332 & -0.125 & 0.460 & -0.433 & 0.003 \\
\hline Moisture & 0.160 & -0.105 & $0.516^{*}$ & 0.156 & $0.683^{* *}$ & -0.232 \\
\hline $\mathrm{TOC}$ & 0.431 & 0.096 & $0.606^{*}$ & 0.147 & 0.383 & 0.006 \\
\hline $\mathrm{TN}$ & 0.222 & -0.005 & 0.468 & 0.278 & 0.473 & -0.081 \\
\hline $\mathrm{CN}$ & $0.529 *$ & 0.164 & $0.646^{* *}$ & 0.027 & 0.279 & 0.042 \\
\hline $\mathrm{TP}$ & -0.023 & -0.065 & 0.401 & 0.367 & $0.583^{*}$ & -0.412 \\
\hline $\mathrm{AP}$ & -0.024 & 0.005 & 0.338 & 0.297 & 0.514 & -0.494 \\
\hline $\mathrm{TK}$ & 0.109 & -0.209 & 0.259 & 0.211 & $0.571 *$ & $-0.559^{*}$ \\
\hline $\mathrm{AK}$ & $0.594^{*}$ & -0.323 & $0.550^{*}$ & 0.483 & 0.230 & -0.010 \\
\hline $\mathrm{NH}_{4}^{+}$ & 0.420 & 0.250 & $0.736^{* *}$ & -0.363 & $0.515^{*}$ & 0.123 \\
\hline $\mathrm{NO}_{3}^{-}$ & 0.335 & 0.439 & $0.676^{* *}$ & -0.213 & 0.323 & 0.081 \\
\hline $\mathrm{MBC}^{-}$ & 0.145 & 0.124 & $0.530^{*}$ & -0.088 & $0.629 *$ & 0.059 \\
\hline $\mathrm{MBN}$ & 0.156 & 0.125 & $0.532^{*}$ & -0.063 & $0.573^{*}$ & 0.015 \\
\hline
\end{tabular}

in the rhizosphere soils did not differ significantly with $\mathrm{N}$ fertilization; soil available nutrients were found to differ significantly with increasing $\mathrm{N}$ fertilization rates. The results of the different soil types showed the same trend. The results of no recorded change in soil total nutrients are consistent with previous studies [11]. The results were also in accordance with previous findings that high $\mathrm{N}$ inputs could result in $\mathrm{NO}_{3}^{-}$accumulation $[3,31]$, and $\mathrm{NH}_{4}^{+}$has the same phenomenon. Tang (2016) suggested that most $\mathrm{N}$-cycle functional genes responded differently to the addition of $\mathrm{N}$ and/or $\mathrm{P}$ [32]. The research shows that although nitrogen fertilizer did not increase total nutrients in the soil, different forms of nitrogen in the soil accumulated, which promoted nitrogen cycling. Although $\mathrm{N}$ fertilizers significantly decreased soil $\mathrm{pH}$ in the rhizosphere under the three soil types, increasing the rate of $\mathrm{N}$ fertilizers did not have a significant decrease in soil $\mathrm{pH}$ for the meadow black soil or the alluvial soil. $\mathrm{pH}$ results for the sandy soil also did not have a significant change with fertilization rates $\left(168 \sim 270 \mathrm{~kg} \mathrm{~N} \mathrm{ha}^{-1}\right)$, although the greatest (312 kg N $\left.\mathrm{ha}^{-1}\right) \mathrm{N}$-induced $\mathrm{pH}$ decrease was observed in this soil, which is consistent with the findings of (NAME), who noted that sandy soil has a lower buffering ability than meadow black or alluvial soils [11]. Increasing $\mathrm{N}$ inputs into agricultural soils has had various adverse effects on crop productivity [33]. In general, $\mathrm{N}$ application can increase crop yields in contrast to crops without the addition of $\mathrm{N}$ fertilizers. Although this increase in crop yield was reflected in the results from our investigation, maize yield did not significantly increase with an increase in the rate of $\mathrm{N}$ fertilizer. Generally, large and excessive amounts of mineral $\mathrm{N}$ fertilizers are used to obtain high yields [2]. The overuse of $\mathrm{N}$ fertilizers has led to several concerns, such as greenhouse gas emissions and water pollution by nitrate leaching and runoff losses [4]. Our study provides a scientific basis for the rational use of nitrogen fertilizer to increase production.

\section{Effects on Microbial Diversity of Rhizosphere Soil}

In the maize agricultural soils of our study, bacterial diversity in the soil rhizosphere was generally lower in the soils that had the highest $\mathrm{N}$ fertilization rates (312 $\mathrm{kg} \mathrm{N} \mathrm{ha}^{-1}$ ), regardless of soil type. This finding was possibly a cause of a large decrease of soil $\mathrm{pH}$ with higher inputs of $\mathrm{N}$, which increased soil acidification and may have resulted in stressful conditions that restrained bacterial growth [3]. However, no significant difference between soil microbial diversity (include alpha diversity and beta diversity) and fertilization treatments in our study was identified; we found that differences among the treatments were more significant than those among experimental replicates. The results indicated that microbial diversity in different soil types was greater than in different fertilization treatments. Our study also found that although there was an effect with $\mathrm{N}$ fertilization on soil microbial diversity, soil type had a greater impact. This finding is in accordance with previous studies that showed soil type to have a significant influence on soil microbial diversity in the rhizosphere [14, 16]. Alluvial soil had the lowest diversity and meadow black had the highest microbial diversity. Yu (2016), using the structural equation model, suggested that soil organic $\mathrm{C}$ is usually considered to influence soil microorganisms [11]. Our results also showed that the meadow black soil had the highest organic carbon content. 


\section{Effects on the Microbial Communities of Rhizosphere Soil}

Weighted Unifrac distance was used to show the beta diversity of the different application rates of $\mathrm{N}$ with the three soil types. By regulating the $\mathrm{N}$ fertilizer rate, we expected the maize rhizosphere to influence the soil microbial communities, a presumption that was not supported by our findings. PCoA and weightedunifracheatmap (Fig. 3) showed that there was no significant effect on soil microbial community structure under different $\mathrm{N}$ application rates; however, results from a few previous investigations were contrary to ours [34]. We believe that there are two main reasons for this result:

1) Crop types: Tardy et al. (2015) suggested that plant species and soil type cooperatively shape the structure of microbial communities in the rhizosphere [16] and pervious investigations have shown that plant species are a major driver of bacterial rhizoplane community composition [35-36]. In our study, using only one type of maize, the composition of root exudates varied from plant to plant and affected the relative abundance of microorganisms in the vicinity of the root [37]; bacteria and fungi have coevolved with plants and show a high degree of host specificity [38], which may be a main factor causing the effect of different $\mathrm{N}$ application rates on rhizosphere soil microbial community structure to not be significant.

2) Soil type: our results also revealed that soil microbial community structure, as well as microbial diversity, was significant among the three soil types regardless of $\mathrm{N}$ application rates; more than 40 species in the genus level were significantly different. Da Silva et al. (2003) suggested that soil type instead of maize cultivar type was the overriding determinative factor that influenced Paenibacillus community structures in the rhizosphere [20]. Schreiter et al. (2014) noted that the rhizosphere effect differed depending on the soil type and the plant growth developmental stage [39]. Other studies have also indicated that soil type or different agricultural practices are dominant factors influencing the rhizosphere microbial community [15, 40-41].

Although the amount of $\mathrm{N}$ application had no significant effect on the total nutrient content in the rhizosphere soil, the $\mathrm{pH}$ value significantly decreased in our study. Soil $\mathrm{pH}$ was the dominant factor that shaped the bacterial community composition, as observed in different managed ecosystems [18, 34, 42]. We used the RDA ordination biplot to identify that $\mathrm{pH}$ was the most important factor influencing rhizosphere soil microbial community. Other parameters such as TK, moisture, and MBC also had an effect on the microbial community structure, but the effect was not significant; soil total nutrients (TN, TOC, TP) had a weak effect on the community composition. This finding is contrary to previous studies that suggested that the bacterial community composition was significantly influenced by $\mathrm{N}$ fertilization rates [3], and that $\mathrm{TN}$ and $\mathrm{TOC}$ were also significantly correlated with phylogenetic diversity [43-44]. This was due to the small changes in soil total nutrients in our study; however, the change of soil pH significantly decreased with an increase of fertilizer application rates. Although $\mathrm{N}$ application did not directly affect microbial composition in rhizosphere soil, it had an indirect affect by changing the $\mathrm{pH}$ level of the soils. This result is consistent with previous studies, which suggested that $\mathrm{N}$ fertilization directly affects soil bacterial richness but indirectly affects bacterial communities through soil acidification and plant community change, indicating distinct controls on soil bacterial diversity and community composition [34].

\section{Relative Abundance of Functional Microbial}

Nutrient cycling microorganisms are important for soil nutrient cycling and plant nutrient utilization [45-46]. Long-term fertilization can directionally change the abundance of certain bacterial phyla [4748]. Our long-term observation data shows that adding nitrogen fertilizer influences the relative abundance of N-cycling function microorganisms in rhizosphere soil. The abundance of AOA, AOB, and cbbl in the meadow black soil (M168, M240, M270, and M312) were higher than that in the sand soil (S168, S240, S270, and S312) and the alluvial soil (A168, A240, A270, and A312) $(P<0.05$, Table 3). Although TK was a significantly positively correlative with the abundance of $\operatorname{nos} Z(\mathrm{r}=0.571, P<0.05)$, there was a significantly negative correlation between $\mathrm{TK}$ and the abundance of $g d h 3(\mathrm{r}=-0.559, P<0.05$; Table 4). This means that the long-term application of nitrogen fertilizer has different effects on different functional microorganisms [49].

The change of phosphate-solubilizing bacteria abundance is sensitive to soil total phosphorus and active phosphorus content in soil in our study. Tang et al. (2016) found that $P$ fertilization resulted in a higher abundance of targeted bacterial phyla and of the whole bacterial and fungal communities [50]. The research, in contrast to our results, may be due to the study of different fertilization treatments under three soil types, which makes up for how the different types of soil phosphate-solubilizing bacteria respond to fertilization. There were significant positive correlations in the abundance of $c b b l$ with the soil water content $(\mathrm{r}=0.516, P<0.05)$, TOC ( $\mathrm{r}=0.606, P<0.05)$, $\mathrm{CN}(\mathrm{r}=0.646, P<0.01), \mathrm{AK}(\mathrm{r}=0.550, P<0.05), \mathrm{NH}_{4}^{+}$ $(\mathrm{r}=0.736, P<0.01), \mathrm{NO}_{3}{ }^{-}(\mathrm{r}=0.676, P<0.01), \mathrm{MBC}$ $(\mathrm{r}=0.530, P<0.05)$, and $\mathrm{MBN}(\mathrm{r}=0.532, P<0.05$; Table 4). They were the most significant factors influencing the community composition, abundance, and activity of the $c b b l$ bacteria [51-52]. The above results show that different nitrogen fertilization rates can change the soil nutrient content, and changes of soil nutrients could promote the abundance of nutrient 
cycling microbial changed, and different soil nutrients can affect different functional microbes.

\section{Conclusions}

Results of the long-term experiments showed that the different fertilization rates of nitrogen could not significantly increase the total nutrient content in rhizosphere soil, but it could significantly change the available nutrients in soil. The increasing fertilization rates of nitrogen effectively reduced the $\mathrm{pH}$ value of the soil. The compositions and diversity of soil bacterial communities did not change by the application of $\mathrm{N}$ fertilizer over the 8-year maize agricultural soils. The relative abundances of the nutrient cycling functional genes in the rhizosphere soil under different nitrogen levels were obviously different. However, soil type was found to have a substantial influence on the structure of bacterial communites of the rhizosphere soil. Soil $\mathrm{pH}$ was the most dominant factor to shape the overall bacterial community composition. Therefore, fertilization rates of nitrogen had an indirect effect on the composition of microbial community in soil by affecting soil $\mathrm{pH}$. As excessive fertilization of $\mathrm{N}$ cannot increase the yield of maize, it is important to regulate fertilization rates to a reasonable level to protect the ecological balance of crop soil.

\section{Acknowledgements}

We would like to thank the Natural Science Foundation of Jilin Province, China (20170101077JC), the Jilin Province Science and Technology Development Plan (20160307006NY), and the Modern Agricultural Industry Technology System (nycytx-38) for assistance in this research.

\section{Author Contributions}

L.M.S., W.T.Y., G.Q., G.Y.H, L.S.X, and W.H.B. conceived the study; L.M.S., W.T.Y., L.L., G.Q., and G.Y.H. performed the experiments; and L.M.S., W.T.Y., and L.L. wrote the manuscript.

\section{Conflict of Interest}

The authors declare no conflict of interest

\section{References}

1. MARKLEIN A.R., HOULTON B.Z. Nitrogen inputs accelerate phosphorus cycling rates across a wide variety of terrestrial ecosystems. New Phytologist, 193 (3), 696, 2012.
2. LASSALETTA L., BILLEN G., GRIZZETTI B., ANGLADE J., GARNIER J. 50 year trends in nitrogen use efficiency of world cropping systems: the relationship between yield and nitrogen input to cropland. Environmental Research Letters, 9, 105011, 2014.

3. SHEN W., NI Y., GAO N., BIAN B., ZHENG S., LIN X., CHU H. Bacterial community composition is shaped by soil secondary salinization and acidification brought on by high nitrogen fertilization rates. Applied Soil Ecology, 108, 76, 2016.

4. ZHANG W., DOU Z., HE P., JU X., POWLSON D., CHADWICK D., NORSE D., LU Y., ZHANG Y., WU L., CHEN X., CASSMAN K.G., ZHANG F. New technologies reduce greenhouse gas emissions from nitrogenous fertilizer in China. Proceedings of the National Academy of Sciences of the United States of America, 110 (21), 8375, 2013.

5. SHEN J.P., CAO P., HU H.W., HE J.Z. Differential response of archaeal groups to land use change in an acidic red soil. Science of the Total Environment, 461 (7), 742, 2013.

6. GAI X., LIU H., ZHAI L., TAN G., LIU J. Vegetable yields and soil biochemical properties as influenced by fertilization in Southern China. Applied Soil Ecology, 107, 170, 2016.

7. BARDGETT R.D., VAN W.H. Belowground biodiversity and ecosystem functioning. Nature, 515 (7528), 505, 2014.

8. FIERER N., LEFF J.W., ADAMS B.J., NIELSEN U.N., BATES S.T., LAUBER C.L., OWENS S., GILBERT J.A., WALL D.H., CAPORASO J.G. Cross-biome metagenomic analyses of soil microbial communities and their functional attributes. Proceedings of the National Academy of Sciences of the United States of America, 109 (52), 21390, 2012.

9. BENDER S.F., WAGG C., VAN M.G. An underground revolution: biodiversity and soil ecological engineering for agricultural sustainability. Trends in Ecology and Evolution, 31 (6), 440, 2016.

10. HE Y., QI Y., DONG Y., XIAO S., PENG Q. Effects of nitrogen fertilization on soil microbial biomass and community functional diversity in temperate grassland in Inner Mongolia, China. Clean-Soil Air Water, 41 (12), 1216, 2013.

11. YU H., GAO Q., SHAO Z., YING A., SUN Y., LIU J., MAO W., ZHANG B. Decreasing nitrogen fertilizer input had little effect on microbial communities in three types of soils. Plos One, 11 (3), e0151622, 2016.

12. LUPWAYI N.Z., LAFOND G.P., ZIADI N., GRANT C.A. Soil microbial response to nitrogen fertilizer and tillage in barley and corn. Soil and Tillage Research, 118 (5), 139, 2012.

13. MIAO Y., STEWART B.A., ZHANG F. Long-term experiments for sustainable nutrient management in China. A review. Agronomy for Sustainable Development, 31 (2), 397, 2011.

14. FIERER N., JACKSON R.B. The diversity and biogeography of soil bacterial communities. Proceedings of the National Academy of Sciences of the United States of America, 103 (3), 626, 2006.

15. XIA N., XIA X., LIU T., HU L., ZHU B., ZHANG X., DONG J. Characteristics of bacterial community in the water and surface sediment of the Yellow River, China, the largest turbid river in the world. Journal of Soils and Sediments, 14 (11), 1894, 2014.

16. TARDY V., CHABBI A., CHARRIER X., BERRANGER C.D., REIGNIER T., DEQUIEDT S., FAIVRE-PRIMOT 
C., TERRAT S., RANJARD L., MARON P.A. Land use history shifts in situ fungal and bacterial successions following wheat straw input into the soil. Plos One, 10 (6), e0130672, 2015.

17. RAMIREZ K.S., LAUBER C.L., KNIGHT R., BRADFORD M.A., FIERER N. Consistent effects of nitrogen fertilization on soil bacterial communities in contrasting systems. Ecology, 91 (12), 3503, 2010.

18. GEISSELER D., SCOW K.M. Long-term effects of mineral fertilizers on soil microorganisms - A review. Soil Biology and Biochemistry, 75, 54, 2014.

19. MARSCHNER P., YANG C.H., LIEBEREI R., CROWLEY D.E. Soil and plant specific effects on bacterial community composition in the rhizosphere. Soil Biology and Biochemistry, 33 (11), 1437, 2001.

20. DA SILVA K.R., SALLES J.F., SELDIN L., VAN ELSAS J.D. Application of a novel Paenibacillus-specific PCRDGGE method and sequence analysis to assess the diversity of Paenibacillus spp. in the maize rhizosphere. Journal of Microbiological Methods, 54 (2), 213, 2003.

21. MENDES L.W., KURAMAE E.E., NAVARRETE A.A., VEEN J.A., TSAI S.M. Taxonomical and functional microbial community selection in soybean rhizosphere. The ISME Journal, 8 (8), 1577, 2014.

22. OLSEN S.R. Estimation of available phosphorus in soils by extraction with sodium bicarbonate. Miscellaneous Paper Institute for Agricultural Research Samaru Pp, 1954.

23. BROOKES P.C., LANDMAN A., PRUDEN G., JENKINSON D.S. Chloroform fumigation and the release of soil nitrogen: a rapid direct extraction method to measure microbial biomass nitrogen in soil. Soil Biology and Biochemistry, 17 (6), 837, 1985.

24. EDGAR R.C. UPARSE: highly accurate OTU sequences from microbial amplicon reads. Nature Methods, 10 (10), 996, 2013.

25. EDGAR R.C. Search and clustering orders of magnitude faster than BLAST. Bioinformatics, 26 (19), 2460, 2010.

26. MAIDAK B.L., OLSEN G.J., LARSEN N., OVERBEEK R., MCCAUGHEY M.J. The Ribosomal Database Project (RDP). Nucleic Acids Research, 24 (1), 82, 1996.

27. YU Z., JR MICHEL F.C., HANSEN G., WITTUM T., MORRISON M. Development and application of RealTime PCR assays for quantification of genes encoding tetracycline resistance. Applied and Environmental Microbiology, 71 (11), 6926, 2005.

28. MAO Y., YANNARELL A.C., DAVIS S.C., MACKIE R.I. Impact of different bioenergy crops on N-cycling bacterial and archaeal communities in soil. Environmental Microbiology, 15 (3), 928, 2012.

29. CHAO A. Non-parametric estimation of the number of classes in a population. Scandinavian Journal of Statistics, 11, 265, 1984.

30. OKSANEN J., BLANCHET F.G., KINDT R., LEGENDRE P., O'HARA R.B., SIMPSON G.L. Vegan: community ecology package. R package version 1.17-6, URL http:// CRAN.R-project.org/package=vegan, 2010.

31. ZHONG W., GU T., WANG W., ZHANG B., LIN X., HUANG Q., SHEN W. The effects of mineral fertilizer and organic manure on soil microbial community and diversity. Plant and Soil, 326 (1-2), 511, 2010.

32. TANG Y., ZHANG X., LI D., WANG H., CHEN F., FU X., FANG X., SUN X., YU G. Impacts of nitrogen and phosphorus additions on the abundance and community structure of ammonia oxidizers and denitrifying bacteria in Chinese fir plantations. Soil Biology and Biochemistry, 103, 284, 2016.
33. LIU Y., PAN X.B., LI J.S. A 1961-2010 record of fertilizer use, pesticide application and cereal yields: a review. Agronomy for Sustainable Development, 35 (1), 83, 2015.

34. ZENG J., LIU X., SONG L., LIN X., ZHANG H., SHEN C., CHU H. Nitrogen fertilization directly affects soil bacterial diversity and indirectly affects bacterial community composition. Soil Biology and Biochemistry, 92, 41, 2016.

35. SAUL-TCHERKAS V., UNC A., STEINBERGER Y. Soil microbial diversity in the vicinity of desert shrubs. Microbial Ecology, 65 (3), 689, 2013.

36. MOHANTY S.R., KOLLAH B., BANERJEE K., DUBEY G., GOUR V.K., SHARMA J., RAO A.S. Rhizospheric microbes associated with bioenergy crops with special reference to Jatropha curcas: A critical review on the prospects and future challenges for sustainable bio-energy production. Scientific Research and Essays, 8 (15), 615, 2013.

37. NIHORIMBERE V., ONGENA M., SMARGIASSI M., THONART P. Beneficial effect of the rhizosphere microbial community for plant growth and health. Biotechnologie Agronomie Societe Environnement, 15 (2), 327, 2011.

38. NOUMAVO P.A., KOCHONI E., DIDAGBE Y.O., ADJANOHOUN A., ALLAGBE M., SIKIROU R., GACHOMO E.W., KOTCHONI S.O., MOUSSA L.B. Effect of different plant growth promoting rhizobacteria on maize seed germination and seedling development. American Journal of Plant Sciences, 4 (5), 1013, 2013.

39. SCHREITER S., DING G., HEUER H., NEUMANN G., SANDMANN M., GROSCH R., KROPF S., SMALLA K. Effect of the soil type on the microbiome in the rhizosphere of field-grown lettuce. Frontiers in Microbiology, 5 (4), 144, 2014.

40. FERREIRA E.P., STONE L.F., DIDINET G.M. Population and microbial activity of the soil under an agro-ecological production system. Rev. cienc. agron, 48 (1), 22, 2017.

41. PII Y., BORRUSO L., BRUSETTI L., CRECCHIO C., CESCO S., MIMMO T. The interaction between iron nutrition, plant species and soil type shapes the rhizosphere microbiome. Plant Physiology and Biochemistry, 99, 39, 2015.

42. SUN R., ZHANG X.X., GUO X., WANG D., CHU H. Bacterial diversity in soils subjected to long-term chemical fertilization can be more stably maintained with the addition of livestock manure than wheat straw. Soil Biology and Biochemistry, 88 (4), 4, 2015.

43. SHEN C., XIONG J., ZHANG H., FENG Y., LIN X., LI X., LIANG W., CHU H. Soil pH drives the spatial distribution of bacterial communities along elevation on Changbai Mountain. Soil Biology and Biochemistry, 57, 204, 2013.

44. CHU H., FIERER N., LAUBER C.L., CAPORASO J.G., KNIGHT R., GROGAN P. Soil bacterial diversity in the Arctic is not fundamentally different from that found in other biomes. Environmental Microbiology, 12 (11), 2998, 2010.

45. FRANCIOLI D., SCHULZ E., LENTENDU G., WUBET T., BUSCOT F., REITZ T. Mineral vs. Organic Amendments: Microbial Community Structure, Activity and Abundance of Agriculturally Relevant Microbes Are Driven by Long-Term Fertilization Strategies. Frontiers in Microbiology, 7, 289, 2016.

46. BANERJEE S. Network analysis reveals functional redundancy and keystone taxa amongst bacterial and fungal communities during organic matter decomposition 
in an arable soil. Soil Biology and Biochemistry, 97, 188, 2016.

47. CHEN C., ZHANG J., LU M., QIN C., CHEN Y., YANG L., HUANG Q., JICHEN W., SHEN Z.G., SHEN Q. Microbial communities of an arable soil treated for 8 years with organic and inorganic fertilizers. Biology and Fertility of Soils, 52 (4), 1, 2016.

48. HELGASON B.L., WALLEY F.L., GERMIDA J.J. Longterm no-till management affects microbial biomass but not community composition in Canadian prairie agroecosytems. Soil Biology and Biochemistry, 42 (12), 2192, 2010.

49. MA W., JIANG S., ASSEMIEN F.E., QIN M., MA B., XIE Z., LIU Y., FENG H., DU G., MA X., ROUX X.L. Response of microbial functional groups involved in soil $\mathrm{N}$ cycle to N, P and NP fertilization in Tibetan alpine meadows. Soil Biology and Biochemistry, 101, 195, 2016.
50. TANG X., PLACELLA S.A., DAYDE F., BERNARD L., ROBIN A., JOURNET E.P., JUSTES E., HINSINGER P. Phosphorus availability and microbial community in the rhizosphere of intercropped cereal and legume along a P-fertilizer gradient. Plant and Soil, 407 (1-2), 1, 2016.

51. YUAN H., GE T., WU X., LIU S., TONG C., QIN H., WU M., WEI W., WU J. Long-term field fertilization alters the diversity of autotrophic bacteria based on the ribulose1,5-biphosphate carboxylase/oxygenase (RubisCO) largesubunit genes in paddy soil. Applied Microbiology and Biotechnology, 95 (4), 1061, 2012.

52. LONG X., YAO H., WANG J., HUANG Y., SINGH B., ZHU Y. Community structure and soil $\mathrm{pH}$ determine chemoautotrophic carbon dioxide fixation in drained paddy soils. Environmental Science and Technology, 49 (12), 7152, 2015. 